ISSN : 2337-5957 / e-ISSN : 2655-2833

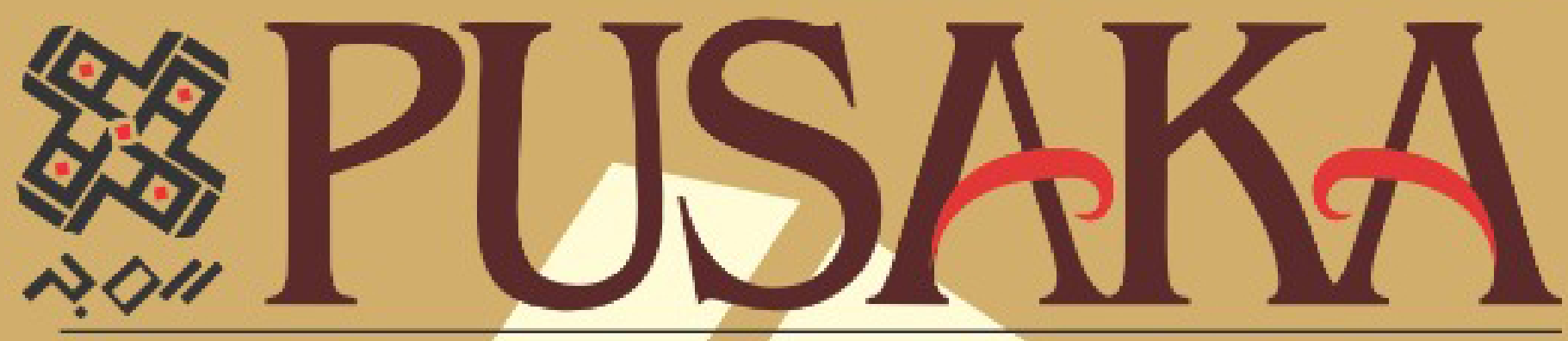

JURNAL KHAZANAH KEAGAMAAN

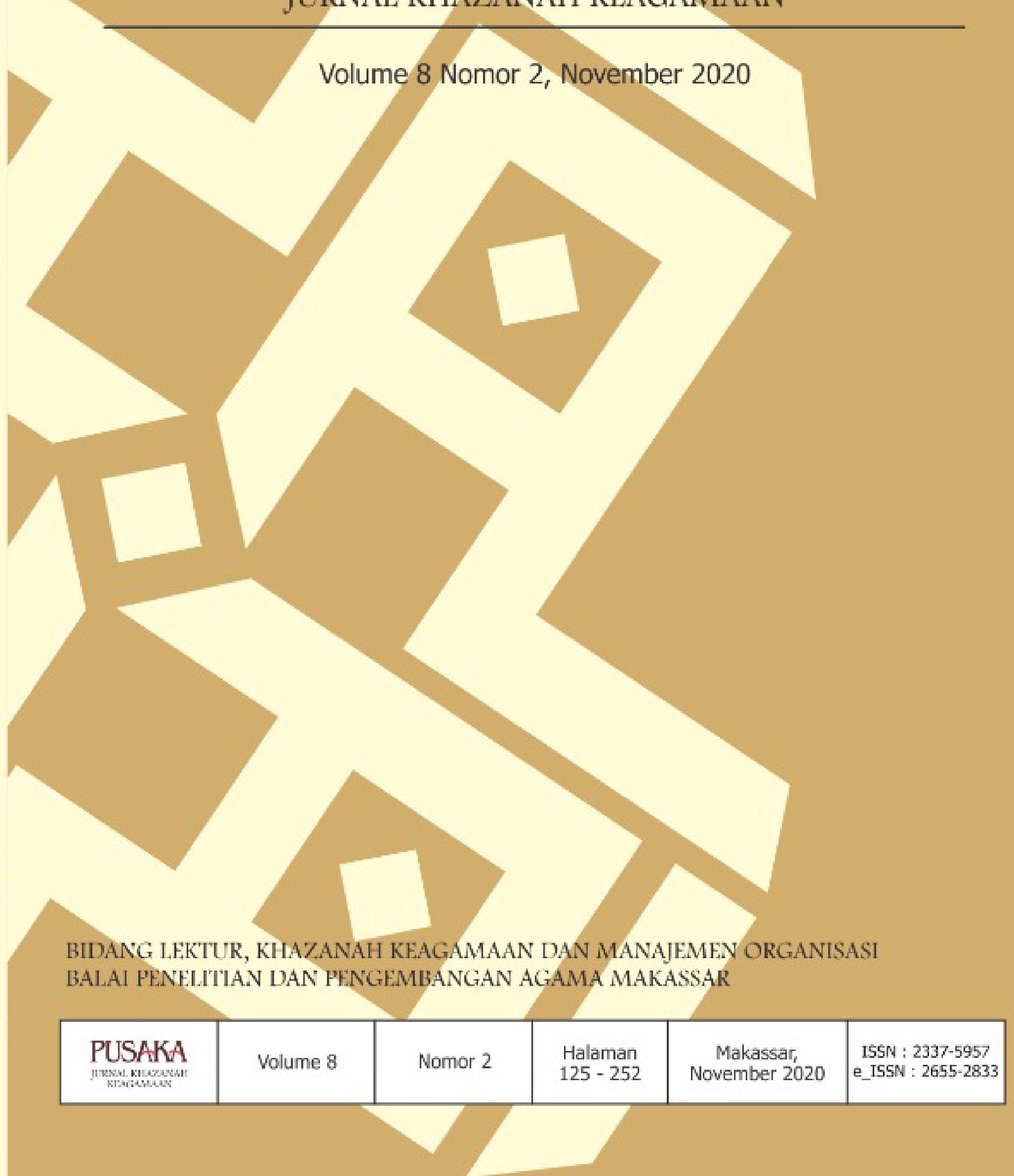


ISSN: 2337-5957 / E-ISSN: 2655-2833

\section{PUSAKA \\ Jurnal Khazanah Keagamaan \\ Vol. 8, No. 2, November 2020}




\section{PUSAKA \\ Jurnal Khazanah Keagamaan}

Vol. 8, No. 2, November 2020

PEMBINA

REDAKTUR AHLI

MITRA BESTARI

PEMIMPIN REDAKSI

DEWAN REDAKSI

KESEKRETARIATAN

Lay Out

ALAMAT REDAKSI
: H. Saprillah, M.Si.

: Dr. H. Abd. Kadir M., M.Ag. (Agama, Balitbang Agama Makassar)

: Prof. Dr. Muhammad Adlin Sila, Ph.D. (Kajian Agama dan Masyarakat, Badan Litbang dan Diklat Kemenag RI) Prof. Dr. H. Idham, M.Pd. (Kajian Agama dan Tradisi Keagamaan, Balai Litbang Agama Makassar)

Dr. H. Muhaemin (Kajian Pendidikan Agama dan Sosiologi Agama, Insititut Agama Islam Negeri Palopo)

Dr. Ulfiani Rahman (Kajian Pendidikan, dan Dirasah Islamiyah, Universitas Islam Negeri Alauddin Makassar).

Dr. Mustolehudin (Kajian Agama dan Tradisi Keagamaan, Balai Litbang Agama Semarang)

: Muh. Subair, SS., M.P.I.

: Abu Muslim, S.HI., M.HI.

Dra. Nelly

H. Muhammad Sadli Mustafa, S.Th.I., M.Pd.I.

Hamsiati, M.Hum.

Husnul Fahimah Ilyas, M.A.Hum

Muhammad Nur, MH.I.

Syarifuddin, S.S., M.Hum.

Wardiah Hamid, S.Ag, M.Hum

: Amru Ichwan Alwy, S.IPI.

Burhanuddin

Darwis, S.Pd.I.

Risma Yuliana Wahab, S.Kom

Syamsuddin, S.M.

: Nur Arisal, SE.

: Balai Penelitian dan Pengembangan Agama Makassar

Jl. A.P. Pettarani No. 72 Makassar 90222

Telp. 0411452952 Fax. 0411452982

Email: pusakajurnal@gmail.com 


\section{PUSAKA \\ Jurnal Khazanah Keagamaan \\ Vol. 8, No. 2, November 2020}

\section{DAFTAR ISI}

Tradisi Siklus Hidup Masyarakat Perkotaan di Era Normal Baru

(Studi Living Qur'an pada Masyarakat Pedalangan, Banyumanik, Semarang)

Mita Melina, Ulfi Putra Sany, dan Mustolehudin

Mengilhami Kreativitas Keberagamaan Masyarakat Melalui Perjumpaan

Islam dan Patuntung di Tanah Toa Kajang

Sylviah dan Abu Muslim

Makna dan Simbol Pada Tradisi Pembacaan Ratek Mauduk

di Komunitas Makassar

Husnul Fahimah Ilyas

Korelasi Fungsional Kalender Islam dan Pembayaran Zakat

Muh. Rasywan Syarif dan Naif

Islamisasi di Ajatappareng Abad XVI-XVII

Ahmad Yani

Merajut Moderasi Beragama dari Tradisi Pesantren

Abd. Kadir M

Jaringan Intelektual Ulama Pinrang

Syarifuddin

Kearifan Lokal Sintuwu Maroso sebagai Simbol Moderasi Beragama 


\section{PENGANTAR REDAKSI}

Pandemi COVID-19 belum berlalu, di tengah penerapan tatanan kehidupan baru yang berbasis pada adaptasi perilaku hidup bersih dan sehat, kini hadir lagi edisi Pusaka Jurnal Volume 8 Nomor 2, November 2020. Sebuah upaya konsisten untuk terus menghadirkan jurnal ilmiah yang berbasis hasil penelitian dalam bidang, lektur dan khazanah keagamaan. Tidak mudah untuk menjaga ritme ketepatan penerbitan dan kualitas artikel yang memenuhi kualifikasi terbaik. Tetapi, artikelartikel pada edisi ini tampak berkembang lebih baik, ditandai dengan semakin minimnya yang melewati ambang batas plagiasi dari artikel-artikel yang diterima. Hal ini menunjukkan kesadaran para penulis akan pentingnya menjaga integritas dan akuntabilitas pribadi sebagai bagian dari masyarakat ilmiah yang bertanggung jawab.

Persebaran wilayah penulis dan wilayah kajian selanjutnya akan menjadi perhatian dalam penentuan artikel yang akan diterima. Hal ini dapat ditunjang oleh penyebarluasan informasi jurnal online dan diikuti oleh peningkatan sitasi jurnal yang menjadi keharusan untuk selalu ditingkatkan. Iklim penulisan artikel yang menjaga integritas penulis dari plagiarisme sekali lagi akan sangat membantu untuk menjaga keberlangsungan kualitas artikel, penyebarluasan artikel, dan ketertarikan para penulis dari berbagai daerah untuk mempercayakan artikelnya menjadi bagian dari terbitan Pusaka Jurnal Khazanah Keagamaan pada edisi-edisi yang akan datang.

Edisi kali diharapkan dapat menghadirkan berbagai artikel yang informatif dan solutif terhadap permasalahan sosial keagamaan dan tuntutan perkembangan zaman. Karena itu, artikel terkait kearifan lokal menjadi warna yang dominan, khususnya yang membincang tentang pengembangan sikap moderasi beragama. Basis artikel sebagai deskripsi empiris dari keadaan masyarakat yang menjadi sasaran penelitian, memperlihatkan wajah dan watak keberagamaan dalam keberagaman yang dinamis. Suku-suku bangsa yang beragama dapat dimaknai sedang berupaya mengangkat citra diri kesukuannya dengan memberi manfaat yang sebesar-besarnya bagi terciptanya kualitas kebangsaan yang lebih baik.

Makassar, 01 November 2020

Pemimpin Redaksi,

Muh. Subair 

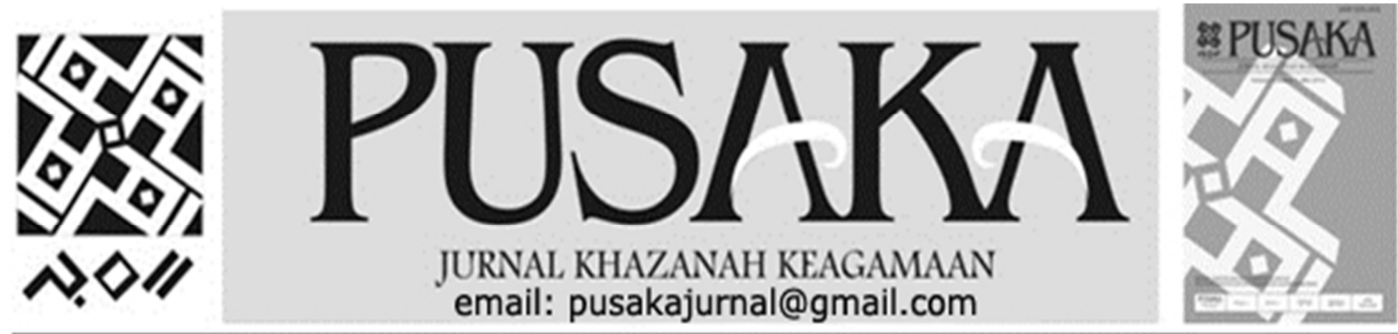

\title{
Mengilhami Kreativitas Keberagamaan Masyarakat Melalui Perjumpaan Islam dan Patuntung di Tanah Toa Kajang
}

\section{Inspiring Community Religious Creativity Through The Encounter of Islam and Patuntung in Tanah Toa Kajang}

Sylviah

Institut Agama Islam Negeri Bone

J1. Hos Cokroaminoto Watampone

Email: lapawawoi41v@gmail.com

\author{
Abu Muslim \\ Balai Penelitian dan Pengembangan Agama \\ J1. AP. Pettarani No. 72 Makassar \\ Email: abumuslim@kemenag.go.id
}

\begin{tabular}{|c|c|}
\hline $\begin{array}{c}\text { Info } \\
\text { Artikel }\end{array}$ & Abstract \\
\hline $\begin{array}{c}\text { Diterima } \\
13 \\
\text { Juli } \\
2020 \\
\\
\text { Revisi I } \\
16 \\
\text { September } \\
2020\end{array}$ & $\begin{array}{l}\text { Relasi Islam dan agama lokal sebagai bagian dari perjumpaan keberagamaan dan kebudayaan } \\
\text { masyarakat, merupakan kajian khazanah keagamaan yang salah satu tujuannya adalah untuk } \\
\text { melihat bagaimana eksistensi agama dan kepercayaan lokal itu dalam menghadapi pengaruh } \\
\text { doktrin dan narasi keberagamaan dari luar. Setelah melakukan wawancara, observasi, telaah } \\
\text { dokumen naskah, dan inventarisasi tradisi lisan, dengan mengacu pada pendekatan sejarah, } \\
\text { penelitian ini menemukan bahwa Tanah Toa Kajang sebagai semua komunitas lokal dengan } \\
\text { kepercayaan patuntung yang telah mandarah daging, dapat tetap menjalankan ajaran } \\
\text { keagamaan yang dianut, dengan melakukan adaptasi kultural dengan Islam sebagai agama } \\
\text { yang hadir dan menawarkan perspektif baru tentang perilaku keberagamaan, namun oleh } \\
\text { komunitas kajang justru dengan idealisme dan kepantuntungan yang dimiliki justru menklaim } \\
\text { bahwa pada prinsipnya ajaran yang dibawa itu adalah ajaran yang juga telah lama dipegangi. } \\
\text { Sesungguhnya Islam itu pada dasarnya lebih duluan lahir di tana toa kajang kemudian } \\
\text { tersebar ke luar. Bangunan narasi ini menunjukkan bahwa kepercayaan Patuntung berhasil } \\
\text { melakukan negoisasi keberagamaan dengan Islam, tanpa harus ada yang menaklukkan dan } \\
\text { ditaklukkan. Dengan kreatifitas yang mereka miliki, mereka berhasil menerjemahkan Islam } \\
\text { sesuai dengan lokalitas dimana mereka berada. } \\
\text { Kata Kunci: tana toa kajang, kreatifitas keberagamaan, kepercayaan patuntung }\end{array}$ \\
\hline $\begin{array}{c}\text { Revisi II } \\
4 \\
\text { Oktober } \\
2020\end{array}$ & $\begin{array}{l}\text { The relationship between Islam and local religions as part of a religious and cultural } \\
\text { encounter in society is a study of religious treasures, one of which aims to see how the } \\
\text { existence of local religions and beliefs is in the face of the influence of doctrine and religious } \\
\text { narratives from outside. After conducting interviews, observations, reviewing manuscript } \\
\text { documents, and an inventory of oral traditions, with reference to the historical approach, this } \\
\text { study found that Tanah Toa Kajang as all local communities with patuntung beliefs that have } \\
\text { been mandated by meat, can continue to carry out their religious teachings, by doing } \\
\text { Cultural adaptation with Islam as a religion that is present and offers a new perspective on } \\
\text { religious behavior, however, by the single community, it is precisely with their idealism and } \\
\text { benefits that they claim that in principle the teachings carried are teachings that have long } \\
\text { been held. In fact, Islam was basically born in Tana Toa Kajang first and then spread to the } \\
\text { outside. This narrative building shows that Patuntung belief has succeeded in conducting } \\
\text { religious negotiations with Islam, without having to conquer and be conquered. With their } \\
\text { creativity, they succeeded in translating Islam according to the locality in which they are } \\
\text { located. } \\
\text { Keywords: tana toa kajang, religious creativity, patuntung belief }\end{array}$ \\
\hline
\end{tabular}




\section{PENDAHULUAN}

Kajang sebagai salah satu bagian dari komunitas lokal di Sulawesi Selatan yang juga memiliki struktur pemerintahan sendiri, sejak dahulu telah menjadi salah satu objek kajian dalam melihat bagaimana Agama Lokal dan Agama Samawi berdialektika dengan caranya sendiri, melalui struktur masyarakat yang sangat khas, dengan tatanan adat lokal dengan perangkat yang sangat kompleks, tetap berusaha eksis dengan lokalitas dan kepercayaan leluhurnya, dalam menghadapi segala bentuk pengaruh eksternal. Kajang yang notabene memiliki alur kepercayaan khusus yakni kepatuntungan tentu saja mempunyai dialektika khusus dalam hal perjumpaannya dengan Islam yang dengan sangat kuat menjadi corak keberagamaan orang-orang Bulukumba, melalui kharisma penyebaran Islam oleh Datu ri Tiro beberapa Abad silam.

Apa yang kita bayangkan ketika kita mengucapkan lokalitas? Daerah pinggiran, non-mainstream, lawan dari pusat, lawan dari universalitas, terbelakang dan anti modernitas. Mungkin kata itu segera yang akan muncul di benak kita. Inilah juga yang acap kali menjadi gambaran kaum terpelajar (Akib, 2003). Bahkan jika negara diposisikan sebagai pusat dan kemoderenan sebagai yang universal, maka lokalitas ini adalah arena yang dianggap disubordinasi oleh Negara maupun modernitas. Konteks ini memunculkan gambar buram tentang lokalitas; kumuh, terbelakang sekaligus tak berdaya.

Namun pandangan lazim bahwa yang lokal adalah yang tersubordinasi, yang selalu kalah dan hanya menjadi objek semata dalam banyak kasus komunitas lokal di Indonesia, tidak sepenuhnya benar. Apa yang digambarkan para antropolog era tahun 70-an yang menganggap bahwa modernitas dan kekuatan negara telah membuat yang lokal dengan eksistensinya tak berdaya lagi, menjadi patut kita pertanyakan kembali. Betul bahwa pada masa Orde Baru, pemerintah telah mengeluarkan berbagai kebijakan yang mengkonstruksi sedemikian rupa kebudayaan bangsa ini. Konstruksi itu memang adalah upaya untuk mematikan yang lokal atau menempatkannya semata barang pajangan yang artifisial. Hanya berguna atau dimunculkan jika sudah dimodifikasi dalam bentuk pariwisata atau souvenir jualan.

Tapi semua hal itu tidak betulbetul mematikan yang lokal. Mereka senantiasa membangun relasi yang berimbang melalui proses-proses negoisasi, adaptasi, bahkan acapkali resistensi. Etnografi Anna Tsing yang memukau tentang Dayak Meratus dalam In The Realm of Diamond Queen: Marginality in an Out of Way Place setidaknya mulai menunjukkan bahwa bicara yang lokal, bukan semata bicara tentang orang-orang yang selalu kalah (Tsing, 1998).

Terlebih, jika kita melihat cara dan sudut pandang metode penyampaian Islam kepada komunitas yang mewakili sebuah sistem kepercayaan monoteisme (percaya kepada Tu Rie' A'ra'na) yang 'terkesan' cukup keras menghantam sistem kepercayaan lokal itu, karena dianggap memiliki potensi kemusyrikan dan kesyirikan, sebab pemujaannya yang sangat kental terhadap roh-roh halus yang dipercaya sebagai bagian dari sistem kehidupannya. 
Acapkali, benturan-benturan tidak terhindarkan terjadi antara penganjur agama Islam, melalui metode dakwah keagamaan, dengan masyarakat komunitas lokal di bawah pimpinan Ammatowa. Beberapa penelitian melihatnya sebagai sistem penyebaran agama Islam yang tidak peka kultur, namun di sisi lain pembenaran atas sikap itu disuarakan atas nama pemurnian akidah.

Tercatat beberapa peristiwa yang terjadi di Tanahtoa Kajang melibatkan semacam ketegangan antara Masyarakat Lokal Kajang dengan pihak luar. Seperti misalnya yang terjadi pada sekitar tahun 1950-1957 ketika terjadi pemberontakan di bawah pimpinan Kahar Muzakkar yang lazim dikenal dengan gerakan DI/TII. Ammatowa ketika itu dengan kewibawaan yang dimiliki, serta kekuatan spiritualitas yang diyakini mampu membentengi ilalang embayya (Kawasan Kajang) dari gempuran pasukan Kahar Muzakkar, dengan membentuk benteng pertahanan yang dikenal dengan Pasukan Dompea.

Kenyataan ini menunjukkan bahwa sesungguhnya lokalitas bukanlah ruang yang diam atau satu letak geografis belaka. Bukan pula hubungan satu arah melulu. Demikianlah, maka jika anda berbicara tentang lokalitas ketika dihubungkan dengan pusat atau yang global tidaklah semata- mata soal yang mendominasi dan tersubordinasi (Barker, 2000). Bukan pula soal kepasrahan yang lokal terhadap dominasi pusat, pengorbanan yang lokal demi kepentingan negara. Lokalitas adalah arena, tempat komunitas yang bermukim di atasnya bergerak, membuat makna baru, membaca ulang, dan ruang-ruang kreatifitas dan lokus negosiasi. Kata Anna Tsing: "An out of The Way place is, by definition, a place where the instability of political meanings is easy to see". (Lokasi terpencil atau komunitas lokal adalah tempat dimana ketidak stabilan makna politik mudah dilihat (Tsing, 1998).

Begitulah komunitas Tanah Toa Kajang ini ketika berhadapan dengan apa yang kita anggap pusat, resmi dan modern. Mereka bukanlah komunitas yang diam. Mereka tidak serta merta lebur dan menjadi tidak berdaya. Mereka membaca ulang, membagun definisi dan membuat makna menjadi tidak stabil. Ketika berhadapan dengan agama 'resmi', seperti Islam, ia tidak serta merta lebur begitu saja dengan Islam dan kehilangan lokalitas mereka. Berbagai ajaran Islam yang diajarkan kepada komunitas ini, dibaca ulang dan disesuaikan dengan konteks mereka sebagai komunitas lokal dengan berbagai kepercayaan dan ritual yang mereka sudah miliki sebelumnya.

Singkatnya lokalitas yang menjadi arena komunitas Tanah Toa Kajang adalah arena mimikris yaitu sebuah peniruan dari lokal terhadap pusat namun diiringi pemaknaan ulang bahkan pengejekan. Jika boleh meminjam apa yang dikatakan Bhaba, maka tindakan komunitas lokal dalam melakukan mimikri adalah: "Mimicry is thus the sign of a double articulation; a complex strategy of reform, regulation and discipline, which appropeiates the Other as it visualizes power" (Bhaba, 1997, p. 152).

Pengalaman masyarakat Kajang
dalam bersiasat, bernegoisasi,
berdialog dan kadang-kadang
meresistensi hal yang dianggap
universal, resmi dan pusat inilah yang
menjadi fokus bahasan dalam tulisan
ini, dengan menjadikan pergulatan
Islam dengan kepercayaan Patuntung 
sebagai arenanya. Dari sini kita bisa belajar bahwa sesungguhnya pada yang lokalitas itulah mozaik kebudayaan disusun dari pertemuan dengan berbagai kebudayaan yang ada, sehingga tidak tepat mengatakan ada kebudayaan yang betul-betul asli tanpa berbaur dengan kebudayaan lain (Parekh, 2004, p. 47)

\section{HASIL DAN PEMBAHASAN Seputar Sejarah Tana Toa Kajang}

Kajang memiliki dua konsep pengertian yang berbeda, yakni Kajang dalam pengertian sebagaimana dalam pasanga serta kajang dalam pengertian sebagai kecamatan. Kajang dalam pengertian pasanga adalah sebidang tanah yang terletak pada Desa Possi Tanah. Sedangkan Kajang dalam pengertian yang lain adalah nama salah satu kecamatan dalam wilayah administratif Kabupaten Bulukumba.

Dari pengertian tradisional sampai pengertian sebagai kecamatan, Kajang mengalami fase-fase perkembangan antara lain periode sebelum ekspansi dari Kerajaan Gowa dimana sejarah Kajang hanya bersumber dari cerita rakyat/mitos. Selanjutnya adalah periode dimana Kerajaan Gowa menyerukan untuk memeluk agama Islam, dimana Kajang termasuk salah satu kerajaan yang menerima Islam tanpa peperangan dengan mengirim utusan mempelajari Islam pada beberapa daerah.

Kemudian pada masa penjajahan Belanda, Kajang berstatus distrik yang bernaung di bawah Onder Afdeling Bulukumba. Sistem tersebut baru berubah setelah terbitnya UndangUndang Nomor 29 Tahun 1959 dimana Kewedanan Bulukumba diganti menjadi daerah Swatantera Tingkat II Bulukumba. Sistim pemerintahan ini berlangsung sampai penyerahan kedaulatan dan diterbitkannya PP nomor 59 tahun 1959 tentang pembentukan kecamatan, sehingga Distrik Kajang diubah menjadi Kecamatan Kajang yang terdiri atas tujuh buah desa yakni Desa Tanah Jaya, Desa Tambangan, Desa Anjuru, Desa Pantama, Desa Lolisang, Desa Lembang dan Desa Lombok. Selanjutnya pada tahun 1965 berdasarkan Surat Keputusan Gubernur Sulawesi Selatan No. 450 dibentuklah lima buah desa, masing-masing Desa Tanah Jaya, Possi Tanah, Tana Towa dan Lembanna (Katu, 1980, pp. 2526).

Kini, jika hendak ke Kajang, kita akan menempuh perjalanan dengan jarak sekitar 95 kilometer dari ibukota Kabupaten Bulukumba atau sekitar 275 kilometer dari Makassar ibukota propinsi Sulawesi Selatan. Manifestasi Kajang dapat secara utuh dilihat pada sebuah desa yang berciri khas serba hitam sebagai simbol kesederhanaan, kesucian dan kesabaran. Desa itu bernama Tana Toa Kajang sebagai wilayah paling luas di Kecamatan Kajang dengan luas wilayah desa kurang lebih 1.820 Ha. Sebagian besar wilayahnya terdiri atas kawasan hutan adat dan ladang (sekitar 800,50 Ha). Desa ini berbatasan dengan Kabupaten Sinjai di sebelah utara, Desa Tambangan di sebelah Selatan, Desa Possi Tanah dan Desa Lembanna di sebelah timur serta Kecamatan Bulukumpa di sebelah barat (Akib, 2003, p. 20)

\section{Kajang dalam Perbincangan Mitologi}

Membincang Kajang, tidak bisa dipisahkan dari informasi yang diperoleh dari cerita turun temurun masyarakatnya, hal ini sangat erat kaitannya dengan mitologi sejarah Kajang. Meskipun kelompok sejarawan 
profesional dengan tegas menuntut dipisahkannya mitos dengan fakta, sebagai antitesis atas keberadaan sejarah tradisional yang seringkali mengawinkan mitos dan fakta, akan tetapi dalam perkembangannya, justru secara genetikal dapat dikatakan bahwa sejarah merupakan anak turunan mitos setelah melalui berbagai tahap evolusi dalam menghadapi seleksi jaman. Sejatinya, sejarah merupakan hasil evolusi dari mitos yang dirasionalisasi, bahkan gen-gen dalam sejarah dewasa ini masih mengandung unsur mitos.

Menurut Horkheimer, mitos adalah keirasionalan, takhayul atau khayalan, pendeknya sesuatu yang tak berada dalam kontrol kesadaran dan rasio manusia. Namun perlu dipahami, bahwa mitos sebenarnya merupakan percobaan-percobaan manusia untuk mencari jawaban-jawaban dari pertanyaan-pertanyaannya tentang alam semesta, tentang dirinya sendiri. Lebih lanjut Max Horkheimer mengungkapkan bahwa telah banyak kegagalan yang diperoleh dari usaha manusia untuk merasionalkan sesuatu yang berbau sejarah, sehingga justru akan terjebak dalam keirasionalirasionalan yang baru, dengan demikian, usaha manusia rasional tidak akan berhasil menghilangkan mitos, tetapi justru hanya akan menciptakan mitos-mitos baru (Sindhunata., 1983). Terkait hal ini, secara tegas sejarawan Taufiq Abdullah menyebut mitos sebagai jawaban atas pertanyaanpertanyaan yang tidak bisa ditemukan jawabannya. Sehingga pemaparan mitos ini perlu ditampilkan sebagai bagian yang tidak bisa dipisahkan dari keberlangsungan sejarah itu sendiri.

Kaitannya dengan Kajang, terdapat beberapa mitos yang berkembang di masyarakat sebagai bagian dari pengungkapan sejarah Kajang. Hal ini justru menarik untuk ditampilkan sebagai manifestasi dari usaha masyarakat Kajang dalam menciptakan sejarahnya sendiri. Mitologi itu diperoleh dari beberapa kisah yang disadur dari pelbagai sumber antara lain:

\section{a. Mitos Mula Taua}

Dikisahkan bahwa pada suatu masa telah datang seorang laki-laki yang tidak diketahui asal-usulnya dengan mengendarai seekor burung. Burung yang dikendarai oleh lelaki itu bernama "Koajang", selanjutnya diambil kesimpulan bahwa sejarah penamaan "Kajang" berasal dari nama burung tersebut. Versi lainnya menyebutkan bahwa burung tersebut datang dengan terbang tinggi, yang dalam bahasa orang-orang Kajang disebut dengan akkoajang, sehingga nama kajang diambil dari kata itu. (Sitti., 1989, p. 5).

Menurut tuturan masyarakat, lelaki tersebut dipercaya sebagai utusan yang turun dari langit yang dikenal sebagai Tomanurung. Lelaki tersebut kemudian dianggap sebagai manusia pertama sehingga disebut mula taua, selain itu juga dikenal dengan istilah Boheta (nenek moyang kita). Selanjutnya, orang inilah yang kemudian dinisbatkan sebagai Ammatowa pertama.

Diceritakan bahwa Ammatowa pertama yang sejak semula telah memiliki pengetahuan yang tinggi terkait pertanian, perikanan dan pemerintahan tinggal bersama istrinya di Tombolo dan melahirkan tujuh orang anak. Setelah ketujuh anaknya menjadi dewasa, merekalah yang kemudian diangkat untuk melaksanakan pemerintahan yang dibentuk sendiri oleh Ammatowa. 
Anak pertama ditunjuk untuk menjadi pemimpin di bidang pemerintahan, hukum sekaligus sebagai koordinator atas jabatan-jabatan lainnya, selanjutnya lebih popular dengan Galla Pantama. Anaknya yang kedua juga diangkat sebagai kepala pemerintahan di Kajang dan bergelar Galla Kajang, anak ketiganya diamanahkan sebagai juru bicara merangkap pengamanan terhadap pelaksanaan ajaran Pasang, sehingga disebut sebagai Benteng Ri Lau yang kemudian lebih dikenal dengan gelar Galla Puto. Anak ke empatnya diangkat sebagai kepala pemerintahan di Lombok bergelar Galla Lombok. Putra kelima diangkat sebagai pengatur perikanan darat dan perikanan laut dengan gelar Galla Anjuru. Kelima jabatan ini, selanjutnya dikenal sebagai lembaga Adat Limaya ri Kajang.

Setelah pengaturan-pengaturan kelembagaan adat telah rampung, Ammatowa sebagai pemimpin tertinggi dalam sistem pemerintahan menganggap bahwa keadaan pemerintahannya sudah stabil. Maka kembalilah ia ke Bottinglangi (dunia atas) dengan jalan immortal (kematian yang lenyap bersama jasad) yang dalam bahasa konjo disebut Assajang (Katu, 1980, pp. 15-17).

b. Kalabbirang: Tuan Laut dan Putri Bambu

Tersebutlah seorang lelaki dari adat Lembang bernama Mado Putta Parang (dikenal juga dengan nama $P u$ Temparang atau tuan laut) telah lama hidup bersama isterinya bernama $P u$ Minanga namun belum juga dikarunai keturunan. Dikisahkan bahwa $P u$ Minanga adalah seorang wanita manang (dalam bahasa setempat diartikan tidak bisa mendapat keturunan).
Pada suatu hari Mado Putta
Parang pergi mencari ikan menggunakan jala. Setiap kali dia membuang jaringnya, setiap itupula tak seekor ikanpun berhasil ditangkap, hal tersebut terjadi terus menerus sampai beberapa kali, hingga akhirnya Mado Putta Parang menyadari bahwa dalam setiap tarikan jalanya selalu saja yang terjaring hanyalah seruas bambu. Anehnya, setiap bambu yang terjaring itu dibuangnya ke laut, pada penarikan berikutnya, seruas bambu itu masih saja terjaring kembali. Akhirnya, Mado Putta Parang kemudian berkesimpulan bahwa rejeki yang diperoleh hari itu hanyalah seruas bambu dan memutuskan untuk membawanya pulang ke rumah.

Setibanya di rumah, bambu itu kemudian diserahkan kepada isterinya, namun bukannya ikut bersyukur, dia justru merasa diperolok-olok dengan perlakuan suaminya karena hanya membawa seruas bambu hasil menjaring ikan padahal yang diinginkannya adalah makanan, kemudian dengan perasaan jengkel sang istri melemparkan bambu itu ke tanah. Lagi-lagi sebuah keajaiban muncul, setiap hewan yang melintasi bambu itu menjadi lumpuh. Melihat keanehan itu, Mado Putta Parang lalu mengambil kembali bambu itu dan menaruhnya di samping gentong (tempat penyimpanan air). Malam itu dan beberapa malam setelahnya dia selalu terbangun karena mendengar seseorang menggigil kedinginan, tetapi tidak bisa mengetahui asal suara itu. Suatu hari, kebetulan bambu itu dipindahkan ke sebuah rak di atas tungku. Setelah itu, tiap malam dia kembali mendengar keluhan orang kepanasan. Akhirnya, dia menyadari bahwa bambu itulah yang pertama kali 
kedinginan di dekat air, lalu kemudian kepanasan dekat api. Maka dipindahkanlah bambu itu di dekat alat tenun.

Mado Putta Parang dan isterinya rutin setiap pagi bekerja di kebun, akan tetapi setiap mereka kembali ke rumah, ditemukannya kain di alat tenunnya menjadi lebih panjang dari sebelumnya, dan air minum selalu habis. Setelah tiga hari, benang tenun nyaris habis terpakai. Mado Putta Parang kemudian memutuskan untuk pura-pura pergi bekerja, namun diamdiam kembali untuk mencari tahu siapa penenun misterius itu. Dia mengintip lewat celah dinding dan alangkah terkejutnya Mado Putta Parang, karena melihat seorang perempuan cantik sedang duduk di dalam kamar. Kemudian dia melompat masuk dan menangkapnya. Karena kecantikannya, Mado Putta Parang ingin menikahinya. Perempuan itu sebenarnya adalah jelmaan bambu yang ditemukannya di laut. Singkat cerita, keinginan Maddo Putta Parang disetujuinya, namun mewanti-wanti agar Mado Putta Parang tidak terkejut, jika nantinya anak-anak mereka lahir sebagai orang-orang aneh. Pernikahan Mado Putta Parang dengan Perempuan jelmaan seruas bambu yang kemudian dikenal dengan nama Batara Daeng Ri Langi melahirkan empat orang anak yaitu: 1). Tu Kale Bojo, tampak seperti labu, karena tidak mempunyai tangan dan kaki yang selanjutnya menjadi penguasa Lembang Lohe di Kajang. 2). Tu Tentaya Matanna, orang bermata Juling yang selanjutnya menjadi penguasa di Laikang. 3). Tu Sapayya Lilana, orang dengan lidah terbelah yang selanjutnya menjadi penguasa/karaeng Kajang. Dan 4). Tu Kaddikilia Simbulenna, perempuan bersanggul kecil, putri satu-satunya yang rambutnya sangat kusut sehingga sanggulnya hanya seukuran buah kemiri.

Ketiga putra Mado Putta Parang yang ibunya dipercaya sebagai Tu Manurung, selanjutnya memegang kekuasaan, dan jabatan yang dalam istilah setempat disebut Kekaraengang. Inilah yang disebut dengan Karaeng Tallua, yang merupakan Kalabbirang dalam struktur pemerintahan adat Ammatowa.

Dari beberapa mitologi tentang Putri Bambu, selain di Kajang, juga ditemukan mitos yang sama di Bone, Luwu dan Gowa. Jika merunut pada kepercayaan orang Kajang yang menyebut bahwa Kajang adalah awal mula segala sesuatu, ada kemungkinan dari keberlanjutan pertautan mitologi putri bambu tersebut. Dikisahkan bahwa setelah anak-anak dari Putri Bambu dengan Mado Putta Parang lahir, dia kemudian menghilang dan muncul lagi di Bone. Di sana dia menikah dan melahirkan tujuh orang anak yang menjadi penguasa di tujuh daerah hadat Arumpone. Lalu dia ke Luwu dan melahirkan enam orang anak yang menjadi hadat Luwu. Terakhir dia ke Gowa dan melahirkan sembilan anak yang menjadi hadat di Gowa (Gibson, 2009, pp. 176-177).

\section{c. Legenda Datu Manila}

Suatu ketika, Datu Luwu yang mempunyai empat orang putri masingmasing bernama Datu Bulaeng Sitobbo, Datu Palia, Datu Jenjengan dan Datu Manila. Mereka berempat selanjutnya melakukan pelayaran ke arah selatan masing-masing dengan perbekalan dan pengiring. Datu Bulaeng Sitobbo mendarat di Gowa, Datu Palia mendarat di Bone, Datu 
Jenjangan di Selayar sementara Datu Manila mendarat di Kajang.

Datu Manila oleh tutur masyarakat disebutkan mengendarai perahu yang atapnya disebut Kajang bulaeng (atap perahu yang terbuat dari emas). Karena kecantikannya, Datu Manila kemudian dinikahi oleh Galla' Puto' dengan mas kawin (sunrang) berupa tanah, yaitu daerah gallarang Puto' yang terletak di sebelah Timur Maccini, bagian pesisir Timur Possi' tana (pusat bumi) Kajang. Konon di sana masih terdapat sebuah kuburan yang dipercaya sebagai kuburan Datu Manila.

\section{d. Legenda Laiju Karaeng Tapau}

Dikisahkan setelah Labbiri'a

Karaeng Kajang I, Tu Sapayya Lilana meninggal dunia, Ammatowa kesulitan untuk menentukan pengganti sebagai pemegang Kalabbirang, sehingga diadakanlah rapat bersama dengan anggota $A d a$ ' Limayya. Hasil rapat memutuskan bahwa untuk mengganti Karaeng Kajang harus diminta dari Gowa. Kemudian Ammatowa bersama Ada' Limayya menghadap Raja Gowa ke IV.

\section{Permintaan}

Ammatowa selanjutnya ditindaklanjuti dengan terlebih dahulu dimusyawarahkan oleh Bate Salapanga ri Gowa sekaligus menentukan pengganti Kalabbirang di Kajang. Akan tetapi, hasil musyawarah tidak menemukan kesepakatan sehingga oleh Raja Gowa menyarankan agar Ammatowa sendirilah yang memegang Kalabbirang. Tetapi Ammatowa menolak dengan argumentasi bahwa dirinya bukanlah turunan karaeng, ia hanya "Adat" bukan karaeng. Akhirnya raja Gowa mengutus adiknya sendiri Laiju Karaeng Tapau menerima Kalabbirang di Kajang sebagai Karaeng Kajang.
Pengangkatan Laiju Karaeng Tapau sekaligus memperteguh eksistensi lembaga adat Karaeng Tallua dan $A d a$ ' Limayya serta peranannya masingmasing.

\section{e. Legenda Jalling Daeng Sirikang}

Legenda ini mengisahkan bahwa di Kajang pernah muncul empat orang yang merupakan Tau Manurung yakni Manurung ri Tanuntung yang selanjutnya menjadi raja Bone bergelar Mangkau, Manurung ri Buatanang selanjutnya menjadi raja Gowa bergelar Sombaya, Manurung ri Tamatte selanjutnya menjadi raja Luwu bergelar Pajung dan Manurung ri Sangkala Lombok yang tetap berdiam di Sangkala dan menjadi Karaeng. Manurung ri Sangkala ini kemudian menurunkan potensinya kepada kedua putranya yakni Gallung Daeng Baukang yang menjadi Karaeng di Bulukumpa serta Jalling Daeng Sirikang yang menjadi Karaeng Kajang.

\section{Ammatowa: Dia yang Tidak Boleh Disebut Namanya!}

Secara etomologi Ammatowa berasal dari dua kata yakni Amma yang dalam bahasa konjo berarti Bapak dan Towa berarti tua. Jadi Ammatowa adalah bapak tua. Menurut pasanga ri Kajang, Ammatowa adalah to manurung yang dipercaya sebagai manusia pertama yang asal usulnya tidak diketahui. Dia mendiami daerah Kajang di atas ketinggian berbentuk Tempurung yang disebut Tombolo, kemudian dikenal sebagai Ammatowa pertama yang kematiannya dipercaya lenyap bersama jasadnya (immortal), sesudah itu meninggalkan keturunan yang disebut Tau Kentarang, dari keturunan inilah menjadi cikal keturunan Ammatowa selanjutnya. 
Jangan pernah menanyakan nama asli Ammatowa (lebih khusus untuk pejabat Ammatowa pertama) kepada masyarakat Kajang. Kesucian dan kekeramatan yang dimiliki membuat orang-orang Kajang bahkan pejabat Ammatowa sekarang pun, jika ditanya tidak akan mau menyebutkan siapa nama aslinya. Hal ini sekaligus merupakan mekanisme pengelolaan kesan sakralisasi yang hendak ditularkan kepada para pemerhati budaya dan sosial masyarakat Kajang agar tidak berbuat semaunya selama berada dalam kawasan adat.

Ammatowa oleh pengikutnya merupakan tempat menyampaikan keluhan dan meminta nasihat dalam segala hal, dia didengarkan dan dituruti, tapi tidak dipertuhankan oleh pengikutnya. Ammatowa adalah manusia biasa yang mempunyai kelebihan, terutama dalam meramalkan hal-hal yang akan terjadi. Kelebihan yang dimiliki oleh Ammatowa ini tidak mungkin dimiliki oleh manusia biasa, sehingga terdapat beberapa syarat yang harus dipenuhi dalam pengangkatan Ammatowa, antara lain:

1) Harus memahami pasanga ri Kajang dan sejarah Kajang serta memiliki kemampuan meramalkan masa depan.

2) Sabar, jujur dan adil serta memiliki kharisma tinggi.

3) Tidak berorientasi duniawi (sederhana).

Membicarakan Kajang, berarti harus siap mengikuti tata krama yang telah berurat berakar dalam sendi-sendi budaya masyarakatnya. Hal paling sederhana setidaknya dapat dilihat dalam sebuah aturan tidak tertulis terkait keharusan memakai pakaian hitam jika hendak memasuki kawasan adat mesti ditaati. Hal ini dilakukan dalam upaya pendalaman nilai-nilai kesederhanaan yang terlebih dahulu harus ditanamkan kepada siapa saja yang hendak mendalami atau sekadar berkunjung ke ilalang embayya, apalagi jika ada keinginan menemui Ammatowa. Hal lain yang juga harus diperhatikan adalah terkait batasanbatasan khusus pengambilan dokumentasi di kawasan ilalang embaya, dalam hal ini tidak dibolehkan bagi siapa saja mengabadikan foto sang Ammatowa serta melakukan aktifitas perekaman dengan sang Bohe. Konon, pernah ada pengunjung yang diamdiam melakukannya namun setelah hendak melakukan backup dan pembacaan ulang, hasil dokumentasinya tidak bisa terbaca (Wawancara dengan Thamrin warga ipantarang embayya Kajang)

Keharusan berpakaian hitam di Kajang terutama di kawasan adat ilalang embayya merupakan pengejewantahan filosofi kesederhanaan. Dikisahkan sebelum manusia dilahirkan ke dunia, terlebih dahulu berada di alam kegelapan yang tidak ada dosa di dalamnya. Untuk menghormati dan mengenang alam itu, masyarakat Kajang kemudian menjadikan warna hitam sebagai bagian dari kehidupannya di dunia. Pakaian adalah simbol pelindung, dan hitam adalah simbol kesucian dan persamaan, sehingga mewujudkan warna hitam/gelap ke dalam pemilihan warna pakaian dipercaya dapat melindungi mereka agar tetap berorientasi pada kesederhanaan dan kesucian jiwa sebagai bekal mengarungi kehidupan sehari-hari. Semua hitam adalah sama, warna hitam menunjukkan kekuatan, kesamaan derajat bagi setiap orang di hadapan Sang Pencipta. 
Di kawasan ilalang embayya terdapat sebuah prinsip hidup yang diperpegangi masyarakatnya hingga kini, yakni prinsip hidup Tallasa kamase-mase atau pola hidup anti kemapanan dan modernitas (Syamsurijal, 2014: 24-25). Cermin identitas kamase-mase sesungguhnya merupakan manifestasi kesederhanaan yang ditanamkan turun-temurun. Prinsip ini mengajarkan sistem kehidupan yang mandiri dan tidak tergantung pada mesin. Semua dikerjakan dengan pola tradisional, mulai dari bercocok tanam, perangkat rumah tangga, mengambil air di sumur, bergotong royong sampai hal-hal yang bersifat teknis seperti menikah, melahirkan dan prosesi kematian semuanya dilakukan sederhana. Tidak ada listrik, tidak ada handphone, dan tidak akan dijumpai kendaraan bermotor di ilalang embayya, sehingga pengunjungpun harus mengadaptasi pola itu dengan hanya boleh berjalan kaki selama berada di dalam kawasan adat. Prinsip ini sangat jelas tercermin dalam pasanga disebutkan:

Anre kalumannyang kalumpepeang

Nurie'a kamase-maseaji

Angnganre na rie'

Care-care na rie, Pammalli juku'

na rie'

Koko na rie', galung na rie', Balla situju-tuju (Usop, 1978, p. 51).

Artinya:

Kekayaan itu tidak kekal

Yang ada hanya kesederhanaan

Makan secukupnya

Pakaian secukupnya, Pembeli ikan secukupnya

Kebun tersedia, sawah tersedia, Rumah seadanya

Ammentengko nu kamase-mase
A'cci'dongko nu kamase-mase A'dakkako nu kamase-kamase A'mia'ko nu kamase-mase

Artinya:

Berdiri engkau sederhana

Duduk engkau sederhana

Berjalan engkau sederhana

Berbicara engkau sederhana

(Mappasomba, 2012, p. 43).

Kebertahanan semacam ini merupakan bagian dari identitas budaya masyarakat Kajang dalam rangka menunjukkan integritas dan jatidirinya. Sejarah mengajarkan mereka makna hidup dengan keutuhan dan kesejatian. Manusia Kajang tidak hanya mengamalkan pesan leluhur tetapi sekaligus mengajarkan kepada masyarakat luar tentang hakikat kesederhanaan sebagai bagian integral dalam diri manusia yang harus selalu dijunjung tinggi.

\section{Islam dan Kajang}

Membaca sejarah agama dari sebuah komunitas tidak bisa dipisahkan dari bangunan budayanya. Di Sulawesi Selatan, budaya menjadi salah satu pintu masuk penyebaran agama Islam. Ada semacam pola kesinambungan yang terbangun antara metode islamisasi yang diterapkan oleh penganjur Islam masa lalu dengan budaya setempat, yang secara santun mengenalkan Islam tanpa mengabaikan sistem budaya yang telah ada sebelumnya. Dalam perkembangannya, Islam kemudian menjadi bagian integral dari tradisi masyarakat yang tidak terpisahkan satu sama lain. Azyumardi Azra bahkan menyebut bahwa Islam dan budaya lokal sebagai satu kesatuan yang embadded dimana Islam telah berurat berakar dalam tradisi kebudayaan di Indonesia. 
Agama Islam masuk ke Bulukumba (Tiro) pada sekitar abad 17 ditandai dengan kedatangan salah satu dari tiga orang Datuk dari Minangkabau yang bernama Abdul Jawad Khatib Bungsu dan mendarat di Bonto Tiro. Penyebaran agama Islam di Tiro berjalan dengan baik, Kerajaan Tiro menyambut baik agama Islam, ketika itu Kerajaan Tiro di bawah pimpinan Raja Tiro V Launru Daeng Biasa yang memerintah antara (15961625). La Unru Daeng Biasa setelah menerima agama Islam kemudian bergelar Karaeng Ambibiah. Beliau adalah cucu ke 4 dari Samparaja Daeng Malaja (Karaeng Sapo Batu) yaitu raja Tiro pertama. Gelar Karaeng Ambibiah diberikan kepada La Unru Daeng Biasa, karena ketika pertama kali mengucapkan dua kalimat Syahadat dengan dibimbing oleh Datuk Ri Tiro. La Unru Daeng Biasa menggigil seperti orang terserang demam malaria. Berikut petikan pengislamannya:

"Wahai tuan, ajariamma agama nuerangantu terekamua antama agama Islam, maka Khatib Bungsu menjawab bahwa tiada Tuhan selain Allah Nabi Muhammad adalah pesuruhnya, maka raja itu mengucapkan kalimat syahadat Asyhadu Allah Ilaha Illallah Wa Asyhadu Anna Muhammadan Rasulullah" (Bahtiar, 2012).

Setelah pengislaman Kerajaan Tiro kepada Launru Daeng Biasa diikuti oleh seluruh rakyatnya, kemudian Datu ri Tiro bertanya kepada Raja, mengenai Kerajaan mana yang terkenal keberaniannya?. Dijawab oleh raja: Kerajaan Kajang! (Aminah, 1989: 9). Selanjutnya, nuansa keislaman di Kajang akan mengantarkan kita pada pembacaan yang timbal balik, di sini kita akan menemukan dua hal terkait proses Islamisasi di Kajang, yakni sebuah proses pembawaan Islam yang berasal dari luar Kajang dan sebuah pemahaman masyarakat yang menyebutkan bahwa Islam sesungguhnya berasal dan bermula dari Tana' Toa Kajang, dan kemudian menyebar luas ke daerah-daerah di luar Kajang. Selain itu, pola penyebaran Islam di Kajang juga mencakup dua aspek yakni sebuah pola penyampaian Islam secara damai serta ada yang melakukannya dengan cara-cara kekerasan.

\section{a. Islam Terlahir dari Tana' Toa (Versi Ammatowa)}

Masyarakat Kajang sebenarnya mempunyai kisah sendiri tentang proses Islamisasi Tana' Toa, diceritakan bahwa kedatangan Datu dari Minangkabau di kerajaan Tiro sampai ke telinga Ammatowa. Konon kabarnya bahwa Datu ri Tiro adalah seorang berilmu tinggi yang membawa ajaran baru ke tanah konjo. Kemudian diundanglah Datu ri Tiro ke Kajang untuk berdebat tentang ajaran yang dibawanya. Dalam perdebatan yang sifatnya saling menjajal kedalaman pengetahuan terkait hakikat manusia itu terjadi adu argumentasi, namun tidak memperoleh titik temu, lalu saling jajal dilanjutkan dengan mengadu kesaktian satu sama lain, namun tetap berakhir seimbang.

Sementara itu, menurut versi Puto Palasa (Pejabat Ammatowa sekarang) menyebutkan bahwa sesungguhnya penyebaran Islam itu beserta segenap proses dunia dan isinya dimulai dari Tana' Toa. Dari situlah selanjutnya Islam menyebar ke seluruh penjuru dunia. "Kunni nampa tassue sulu" : berawal dari sini lalu tersebar keluar), begitu kata Ammatowa. (Wawancara dengan Ammatowa) 
Bahkan terdapat kepercayaan yang menyebutkan bahwa secara kesuluruhan Alquran mulanya berjumlah 40 juz, 30 juz kemudian dipercayakan kepada Nabi Muhammad untuk menyebarkannya melalui tanah Makkah. Sementara 10 juz sisanya tersimpan di Tana' Toa. Inilah yang selanjutnya oleh masyarakat Kajang dalam kepercayaan Patuntung disebut Pasanga.

Belakangan, kepercayaan Patuntung sebagai budaya spiritual di Kajang mengalami sinkretisasi sedemikian rupa dengan mendapat pengaruh ide spiritual terkait penghayatan dan pengamalan ajaran Islam. (guru sara tangttappa ri patuntunga ta la assai kaguruanna, guru patuntun tangattappa ri guru sara'a ta ala assai kapatuntunganna: ulama yang tidak percaya pada patuntung tidak sah pengetahuannya, dan seorang guru patuntung yang tidak percaya kepada ulama tidak sah kepatuntungannya). Manifestasi ajaran pasanga hakikatnya adalah Tapakkoro sebagai wahana menghubungkan dengan zat Ilahi dilandasi suasana spiritual mendalam. Legitimasi terhadap keadaan ini dikenal dengan ungkapan "je'ne talluka sambayang tangattappu" secara harfiah diterjemahkan wudhu yang tidak pernah batal dan shalat yang tak pernah berhenti (Akib, 2003, pp. 42-44)

\section{b. Kajang Belajar Islam: 3 Utusan 3 Kiblat!}

Mengetahui keberadaan Datuk dari Minangkabau yang berhasil mengislamkan Kerajaan Tiro, Ammatowa yang ketika itu dijabat oleh Bohe Poddo ri Pangi kemudian mengutus utusan pertamanya yakni Janggo Tujarra ke Tiro untuk belajar Islam. Kepada Datu ri Tiro dia mendalami agama Islam yang berhubungan dengan masalah ibadah, setelah merasa cukup, Janggo Tujarra kemudian kembali ke Kajang dengan membawa dan mengajarkan ilmu keislaman yang diperolehnya antara lain:

1) Dua Kalimat Syahadat

2) Baca Doa Rasul dan Baca Talkin

3) Tata cara yang menyangkut kematian (Kalabbusang umuru)

4) Tata cara pengembelihan hewan (Kallong Tedong)

5) Bersujud ke arah kiblat di sebelah barat

Melihat ajaran yang dibawa oleh Janggo Tujarra ini, Ammatowa merasa kurang puas. Bahkan Ammatowa menolak untuk bersujud ke Kiblat arah barat. Berikut petikan penolakan Ammatowa:

Agama Islam yang dibawa oleh Datuk ri Tiro, tidak dapat diterima oleh Ammatowa, karena menurutnya tidak mungkin Ia dan pengikutnya bersujud ke barat. Mereka beranggapan bahwa bersujud ke arah kiblat di sebelah barat sama saja dengan bersujud ke Tiro (yang secara kebetulan berada di sebelah barat Kajang). Padahal tempat suci mereka adalah Tombolo (Mattulada., 1961, p. 53)

Maka dari itu, Ammatowa kemudian mengutus Janggo Toa untuk belajar Islam kepada Datu Patimang di Luwu dan Tosora Wajo. Dia belajar 6 tahun lamanya, setelah merasa puas, kembalilah Janggo Toa ke Kajang untuk mengamalkan Ilmu yang diperoleh antara lain:

1) Mengaji mulai Kul-huallah sampai pada ayat Kul-Muflihun (Kemungkinan ajaran yang dimaksud adalah Alquran sampai 
khatam. Simbol khatam Alquran bagi masyarakat Sulawesi Selatan adalah membaca surat An Ikhlas, Al Falaq, An Nas diikuti dengan membaca Al Fatihah, lalu ditutup dengan membaca surat Al Baqarah ayat 1-5 (di akhir ayat: ulaika ala hudamminrabbihim wa ulaika humul muflihun). Inilah mungkin yang dimaksud memulai dengan Kul-Huallahu Ahad (ayat 1 surah al Ikhlas) berturut- turut sampai ayat Kul Muflihun (kalimat terakhir ayat 5 surah Al Baqarah).

2) Baca doa Talkin dan Kalimboang tau (perkawinan)

Lagi-lagi Ammatowa merasa bahwa ilmu yang diperoleh Janggo Toa ini belum memadai. Selanjutnya Datuk ri Tiro menyarankan kepada Ammatowa mengutus lagi salah seorang untuk belajar kepada Datu Ri Bandang di Bontoala Gowa. Maka diutuslah orang ketiga yakni Towasara Daeng Mallipa. Ketika tiba di Bontoala, Towasara Daeng Mallipa tidak begitu saja mendapat ijin dari Raja Gowa untuk menimba ilmu kepada Datu Ri Bandang, tetapi sebelumnya harus melewati ujian yang dari Raja berupa memberi minuman 40 orang tawanan yang sedang berpanaspanas di halaman istana menggunakan cerek yang dibawanya dari Kajang sebagai tempat minumnya dalam perjalanan. Tusara Daeng Mallipa sontak menjadi gusar hatinya karena persediaan airnya tinggal sedikit sementara orang yang hendak diberi minum jumlahnya banyak.

Lalu menengadahlah Tusara Daeng Mallipa sembari tunduk dan menyetujui permintaan itu. Selanjutnya ia berdiri kembali untuk selanjutnya memberi minum kepada 40 tawanan. Anehnya, semua tawanan bisa minum sampai puas sementara air dalam cereknya tidak juga habis. Melihat hal tersebut, bertitahlah sang Raja: Engkaulah orang yang pantas menuntut ilmu agama Islam, sekarang berangkatlah engkau ke Bontoala, di sanalah tempatmu belajar (Hasyim, 1981, pp. 40-41).

Kepada Datu Ribandang dia mengaji 6 tahun lamanya lalu kembali ke Kajang dengan membawa pokok ajaran:

1) Bacaan Alquran mulai dari ayat Wadduha sampai Kul Muflihun

2) Hukum dan tata cara perkawinan

3) Talkin

4) Shalat dan tata caranya

5) Haji serta rukun dan syaratsyaratnya

6) Syahadat, Zakat, Puasa, dan Pappatamma (Upacara khatam Alquran)

Melihat ajaran yang dibawa oleh Towasara Daeng Mallipa, Ammatowa akhirnya merasa puas dan membolehkan agama Islam masuk ke Kajang dengan ketentuan daerah Kajang dibagi menjadi dua bagian yakni (Cahaya., 2014, pp. 33-34). Pertama, Laukang Tuli: Pogaui gau'na gurua, wilayah bagian selatan yang menjadi batas daerah penyebaran Islam yang dibawa oleh Towasara Daeng Mallipa. Di daerah ini, diajarkan agama Islam yang diperoleh dari Datuk Ri Bandang. Kedua, Rajangan Limba: Kowasai i Amma, wilayah bagian utara sebagai daerah kekuasaan Ammatowa. Di sini yang boleh diajarkan hanyalah hukum-hukum yang dibawa oleh Janggo' Toa.

Dalam berbagai literatur juga dijelaskan bahwa proses islamisasi di daerah sekitar Kajang dimulai ketika Abdul Khatib Bungsu yang kemudian 
bergelar dengan Datuk ri Tiro, meyebarkan Islam di sekitar Tiro, sekitar abad ke-16 (Katu, 2003). Di Kajang sendiri proses penerimaan Islam tidaklah serta-merta, apalagi di daerah Kajang memiliki sistem tradisi dan kepercayaan tersendiri, mereka memiliki Amma Toa sebagai Penghulu adat dan dianggap pemimpin spiritual yang tertinggi.

Apalagi ada beberapa kebiasaan-kebiasaan masyarakat adat di kajang yang dilarang oleh agama Islam misalnya minum tuak dan makan babi. Namun tentu saja sebagai kerajaan yang berada dibawah naungan Gowa yang telah memeluk Islam, maka komunitas adat yang ada di Kajang inipun harus rela menerima agama baru tersebut (Cence, 1931, pp. 2-3).

\section{Relasi Islam dan Kepercayaan Patuntung di Tanatoa Kajang}

Penerimaan komunitas Amma

Toa terhadap Islam ini tidaklah secara totalitas menerima apa yang dikandung dalam ajaran islam, di satu sisi mereka tetap ingin mempertahankan beberapa keyakinan mereka, seperti keyakinan akan pasanga ri Kajang, Amma Toa sebagai titisan Yang Maha Kuasa atau To rie Ara'na dan juga beberapa praktek-praktek ritual lainnya. Hal-hal seperti itu tentu saja tidak dibenarkan oleh Islam. Menurut cerita Galla Puto saat itu terjadi pertarungan antara Amma Toa dengan penganjur Islam yang datang (Datuk ri Tiro) pertarungan itu diawali dengan perdebatan persoalan hakiki, pertarungan yang berlangsung cukup lama ini akhirnya berlangsung imbang. Pertarungan kemudian dilanjtkan dengan adu kesaktian, inipun akhirnya berakhir imbang. Akhirnya saat itu antara Amma Toa, Karaeng
Kajang dan penganjur Islam yang datang (tidak jelas apakah Datuk ri Tiro yang dimaksudkan) sepakat untuk membagi wilayah Kajang ini. Ada daerah dimana tradisi Pasanga yang berlaku yang dikemudian hari dikenal sebagai Tanah Toa dan ada daerah dimana ajaran Islamlah yang berlaku. Datuk ri Tiro menerima hal ini, karena pada prinsipnya apa yang dilakukan oleh masyarakat adat di Kajang tentang proses ritual dan keyakinan ada kemiripan dalam Islam. Sejak saat itulah wajah Komunitas Tanah Toa Kajang menjadi dua, sekaligus saat itu pula Islam diterima di daerah ini.

Selanjutnya untuk melihat bagaimana perjumpaan Islam dengan Patuntung sebagai sebuah kepercayaan lokal di tanah toa Kajang, dapat dilihat dengan menyimak prosesi itu melalui sebuah ritual yang masih hidup dalam komunitas Kajang, Akkalomba.

Malam itu suasana kawasan adat (ilalang embayya) yang biasanya sunyi senyap, tampak ramai. Orangoarang berdatangan dari berbagai penjuru sambil membawa makanan. Di tempat pelaksanaan acara nampak beberapa lampu pelleng (semacam pelita yang dibuat dari satu jenis tumbuh-tumbuhan yang bernama pelleng) dipasang, Suasana dirumah itu nampak terang dan mulai ramai didatangi oleh orang. Sesekali gendang dipukul untuk memberi tanda kepada yang lain bahwa sedang ada ajjaga (pesta atau keramaian) di tempat tersebut. Malam itu memang diadakan pajagaan (pesta) oleh salah satu masyarakat adat Tanah Toa Kajang

Selepas magrib, beberapa penghulu adat tampak sudah berdatangan, mereka duduk di tempat yang sudah disiapkan. Kepala dusun 
benteng dan wakil amma Toa juga sudah datang. Saya sendiri dipersilahkan duduk disamping wakil Amma Toa. Disebelah saya duduk Tamrin (yang mendampingi saya selama dilapangan). Ia lalu membisikkan bahwa sekarang ini saya lagi duduk secara adat (accidong ada'). Setelah semua duduk pada tempatnya gendang mulai ditabuh, beberapa orang mulai melantungkan kelong Pajaga, (lagu untuk pesta). diiringi dengan bunyi gendang. Makanan mulai disajikan kepada para pemangku adat, ini diistilahkan dengan attoana ada'. Masing- masing dihidangkan satu dulan makanan dihadapan para pemangku adat, termasuk dihadapan saya. Juga dihidangkan Tuak Pahit sebagai minumannya. Salah seorang dari yang punya hajatan mebisiki saya, apakah saya bisa minum tuak seperti ini, saya mengangguk. Dia kemudian berkata bahwa acara adat seperti ini, apalagi kalau ada attoana ada" tidak absah apabila tidak disuguhkan Tuak.

Menjelang pertengahan malam, acara puncak mulai dilaksanakan. Anak kecil yang mau di kalomba dibangunkan dari tidurnya. Lalu ditengah malam dengan cuaca yang lumayan dingin, anak kecil dengan usia sekitar 2 tahun itu mulai dimandikan. Setelah itu lalu dipakaikan Tope (sarung hitam khas kajang) dan baju. Setelah acara ini selesai anak itu kemudian dibawah ke ruang tengah. Di sana telah tersaji beberapa makanan. Anak kecil ini kemudian dikalungi dengan kampalo (sejenis makanan dari bersa ketan yang dibungkus dengan daun kelapa). Setelah itu beberapa orang kemudian massolo yaitu memberikan sumbangan uang yang nantinya, pada acara yang diadakan oleh yang menyumbang pihak yang punya hajatan saat ini akan menyumbangkan pula uangnya.

Acara ditutup dengan

permohonan doa dari Sanro:

Oh To Rie Akra'na kisarea mae kasalamakkang Kasalamakang mange ri ana cucungku Kasalamakkang mange ri tau tabba

Nabi Muhammad ri Tompo,na Ulungku... barakka....barakka ....barakka....Kun fayakun (Oh To Rie Akra'na (Tuhan Yang Maha Berkehendak) berikanlah kami keselamatan Keselamatan bagianak cucu kami. Keselamatan bagi orang banyak Nabi Muhammad diatas kepalaku semoga berberkat (diucapkan tiga kali). Kun Fayakun....!)

Inilah salah satu acara ritual adat akkalomba yang acap kali dilakukan oleh masyarakat tanah Toa Kajang yang berada di kabupaten Bulukumba ini. Acara ini biasanya dilakukan untuk bayi atau untuk anakanak kecil yang ada didaerah ini agar terhindar dari penyakit. Inilah salah satu tradisi masyarakat Tanah Toa Kajang yang merupakan bagian dari keyakinan Patuntung yang ada dimasyarakat tersebut. Namun dalam praktiknya kini tradisi itu sudah berbaur dan kawin mawin dengan ajaran Islam, seperti yang tercermin dalam doa yang diucapkan oleh sanro tadi.

Mari kita bayangkan bagaimana To rie akra'na dan nabi Muhammad menjadi satu bagian dalam doa dan diucapkan dalam satu tarikan nafas. Inilah salah satu penggalan episode, di mana komunitas Tanah Toa Kajang ini menarik Islam bertemu dengan tradisi mereka.

Tentu saja ini belum berakhir. Mari kita simak sebuah penceritaan 
berikut ini yang dituturkan dengan apik oleh Galla Puto (juru bicara Amma Toa, nama aslinya Puto Beceng).

Syahdan, kedatangan Datuk ri Tiro diketahui oleh Amma Toa, yang juga mengetahui bahwa Datuk ri Tiro ini datang membawa ajaran baru. Selain itu datuk ri Tiro juga diketahui memiliki ilmu yang tinggi. Lalu diundanglah Datuk ri Tiro untuk mengetahui apa maksud dan tujuannya, serta ajaran apa yang dibawanya. Akhirnya terjadilah perdebatan yang menarik antara keduanya seputar hakikat ketuhanan dan hakikat diri manusia. Dalam perdebatan yang sifatnya saling menjajal kedalaman pengetahuan itu diceritakan bahwa kemampuan keduanya berimbang. Setelah itu keduanya berusaha saling menjajal kesaktian masing- masing, yang kemudian juga berakhir imbang. Saat itu Datuk ri Tiro menyusun telur sampai tingginya melewati puncak rumah. Namun Datuk di Tiro dibuat terkesima karena Amma Toa sendiri menunjukkan kesaktiannya dengan mengambil telur itu mulai dari tengah, dan telur itu tetap tersusun, tidak ada yang jatuh. Pertarungan lalu dilanjutkan mereka berdua melompat kepelepah pohon kelapa, Datuk ri Tiro berdiri di atas pelepah itu, sedangkan Amma Toa berdiri dibawahnya dengan kepala menghadap ke tanah. Setelah pertarungan ini, mereka lalu ngasoh dibawah pohon kelapa tersebut. Amma Toa lalu menawarkan apakah Datuk ri tiro ingin minum air kelapa, Datuk ri tiro mengiyakan, lalu Amma Toa tanpa memanjat berhasil mendapatkan beberapa butir pohon kelapa, dia hanya menunjuk buah kelapa di pohonnya dan kelapa itu jatuh ketanah. Datuk ri Tiro tersenyum, lalu berkata: "kenapasusah-susah menjatuhkan kelapanya ketanah". Datuk ri Tiro lalu berdiri dan melambaikan tangannya kearah pohon kelapa, pohon kelapa itu tiba-tiba merunduk, lalu dengan gampang Datuk ri tiro memetik buah kelapa tersebut, kini Amma Toa yang dibuat tercengang.

Bagi komunitas Tanah Toa Kajang, seperti yang diungkapkan oleh Amma Toa cerita ini menunjukkan bahwa antara ajaran Islam dengan kepercayaan Patuntung sejak awal tidak ada yang saling menaklukkan. Kedua-duanya adalah sama- sama kebenaran dan karena itu mestinya yang terjadi adalah dialog dan saling mengisi antara keduanya. Dalam pasanga ri kajang (wahyu yang turun di Kajang) hal ini ditegaskan dengan ungkapan

Guru Sara' tala tappa ri patuntung tala assai kaguruanna, sanro tala tappa ri sara' tanga assai patuntunganna

Artinya: Seorang ahli syariat (Islam) tidak percaya kepada Patuntung tidak absah keahliannya, sedangkan Sanro (ahli patuntung) tidak percaya kepada Syariat (Islam) tidak sah ke-patuntungannya (Katu, 2003).

Atas dasar inilah komunitas Tanah Toa menerimna Islam sebagai agama resmi, namun dalam prakteknya tidak mesti sama dengan yang resmi itu sendiri. Mereka mendialogkan antara islam yang resmi dengan keyakinan Patuntung. Ini dapat kita lihat dalam peraktek keberagamaan mereka seperti shalat, haji dan soal keimanan terhadap wahyu Tuhan.

Dalam hal shalat misalnya, komunitas Tanah Toa ini juga 
mengenalnya, namun bagi mereka shalat tidak mesti seperti dalam tuntunan syariat Formal karena bagi mereka:

Pakabajiki ateka'nu Iyamintu agama Naiyantu sembayangnga Jaman-jamanji (gau'ji).

Pakabajiki gau'nu Sara-sara makana'nu Nanulilian latatabaya

Artinya:

"Perbaikilah hatimu, karena itulah agama. Adapun sembahyang itu pekerjaan saja. Perbaikilah tindak tandukmu, sopan santun dan kata-katamu, agar jauh dari segala cela." (Ammatowa).

Dalam ungkapan lain di pasanga disebutkan: "Je'ne Talluka Sambajang Tamattappu" (Air wudhu yang tidak pernah batal dan sembahyang yang tdak pernah putus). Pemaknaan tentang sembahyang bagi komunitas ini, semakin jelas, seperti yang tersurat dalam teks tadi. Bahwa yang namanya wudhu ataupun sembahyang tidaklah harus dibatasi dengan waktu atau sekedar aturan formal belaka, tetapi yang lebih penting adalah hikmah dari ritual itu dalam kehidupan sehari-hari. Keberadaan kita di dunia senantiasa diwarnai oleh makna-makna dari kesucian berwudhu dan ketawaddhu-an dari shalat kita.

Demikian juga dalam hal haji, mereka melaksanakan tetapi cara yang dilakukannya berbeda dengan cara dalam agama Islam. Ada dua cara mereka melakukan tradisi haji ini:

Pertama; Akkattere, yaitu tradisi potong rambut yang diwajibkan sekali bagi orang-orang dalam komunitas ini. Akkattere ini justru dimaknai sebagai hajinya orang komunitas Tanah Toa Kajang, dan bukan bagian dari aqiqah sebagaimana dalam ajaran Islam. Tentu saja yang penting dalam tradisi ini adalah bagaimana membangun relasi dan kehidupan sosial yang lebih baik di antara masyarakat Tanah Toa Kajang. Dan menurut Puto Beceng ini adalah salah satu hikmah yang paling subtansial dari haji.

Kedua; Tradisi haji yang dilaksanakan di Puncak Gunung Bawakaraeng. Dalam tradisi ini diyakini bahwa proses pelaksanaan haji juga bisa dilaksanakan dengan naik di puncak Bawakaraeng, di sanalah dilaksanakan ritual haji sebagaimana orang lain yang melaksanakannya di Mekkah.

Soal keyakinan terhadap wahyu Tuhan, komunitas ini sama dengan Islam. Mereka percaya bahwa Tuhan menurunkan wahyu kepada para nabiNya yang kemudian menjadi Kitab suci para penganut ajaran-Nya. Mereka juga meyakini al- Qur'an sebagai kitab suci yang diturunkan bagi mereka sebagai umat Islam. Hanya saja bagi masyarakat kajang Qur'an bukanlah 30 juz, tetapi 40 juz. 10 juznya itu adalah Pasanga ri kajang. Bagi masyarakat kajang justru sepuluh juz yang terakhir inilah yaitu Pasanga ri kajang yang menempati tempat tertinggi dalam urutan wahyu, barulah kemudian alQur'an. Kenapa al-Quran menempati urutan kedua, jawabannya karena ia telah dituliskan dan terhimpun dalam teks. Bagi orang Kajang ketika Wahyu di bakukan dalam teks, maka ia sudah menjadi idiologis dan sarat kepentingan. Bukankan teks tertentu akan menunjuk pada kebudayaan, idiologi dan kepentingan tertentu pula. Ini tentunya berbeda dengan asumsi wahyu yang di anut kalangan Islam resmi (baca; Islam Arab). Dimana bagi Islam yang seperti ini wahyu adalah apa yang telah dibakukan dalam teks mushab Ustmani yang sekarang 
menjadi pegangan mereka. Diluar itu berarti bukan wahyu, meskipun sesungguhnya tanpa mereka sadari atau pura-pura tidak sadar diluar teks baku mushab Ustmani di kalangan Islam resmi (Arab) sendiri, terdapat teks lain.

Karena cara pemaknaan mereka seperti ini terhadap ajaran Islam, beberapa kalangan, khususnya dari Islam modernis sering menganggap cara-cara ibadah komunitas Tanah Toa Kajang berbau musyrik. Lalu ramairamailah para dai berdatangan ke daerah ini demi meng-"Islamkan" mereka secara sempurna. Yayasan UMI (Universitas Islam Indonesia) misalnya, sejak tahun 1995 telah menjadikan daerah ini sebagai daerah binaan khusus. Demikian halnya dengan pihak Muhammadiyyah, NU dan Depag, sejak tahun 70-an, kelompok-kelompok agama ini giat melakukan Peng-"Islam"-an terhadap komunitas ini.

Bahkan Saat ini proses islmisasi di daerah ini bukan lagi kewat gerakan kultural berupa dakwah atau pendidikan, tetapi sudah mengarah kepada pengaturan lewat Perda-perda yang dikeluarkan oleh pemerintah daerah kabupaten Bulukumba. Perda tersebut antara lain: Perda no 03/2002, tentang Larangan, Pengawasan, Penertiban dan Penjualan Minuman Beralkohol, Perda no 02/2003 tentang Pengelolaan Zakat Profesi, Infaq dan Shadaqah, Perda no 05/2003 tentang berpakaian muslim dan muslimah, Perda nomor 06/2003. tentang Pandai Baca Al-Qur'an Bagi Siswa dan Calon Pengantin.

Meskipun demikian komunitas ini tidaklah takluk dengan proses islamisasi yang semakin kuat terhadap mereka. Mereka tetap kukuh menjalankan Islam yang mereka pahami selama ini dari hasil dialognya dengan tradisi yang mereka miliki. Sesekali nampak menyembul perlawanan-perlawan simbolik mereka terhadap purifikasi islam ini dalam dialog yang terkadang mereka lakukan dengan orang-orang dari luar. Seperti yang terjadi ketika kami berkunjung ke komunitas ini (Adhan, 2005)

Saat itu setelah basa-basi sejenak dan menyantap suguhan khas tanah Toa, kamipun bercakap-cakap dengan Amma Toa. Dalam percakapan itu tiba-tiba saja Amma Toa melontarkan pertanyaan. "Kalian ini, anak-anakku tentu adalah orang-orang pintar, karena itu saya mau tanya, dalam sembahyang kalian sesungguhnya meyembah siapa, siapa yang anda bayangkan ketika meyebut nama Tuhan dalam shalat"?

Saya terperangah.... Saat itu kami semua diam, harus saya akui secara pribadi pertanyaan ini sangat sulit. "Pertanyaan ini pertanyaan hakikat, mirip pertanyaan Syekh Siti Jenar di hadapan sidang wali di jawa tempo dulu". Batinku saat itu .

Melihat kami terdiam, Amma Toa lalu melanjutkan bicaranya. "banyak di antara kita dalam sembahyang hanya membayangkan huruf- huruf dan nama Tuhan, padahal itu bukanlah Tuhan, dan bila itu dilakukan maka sesungguhnya kita sudah terjebak kearah kemusyrikan". "Kami sangat berhati-hati dalam hal itu, makanya kami di sini sangat mementingkan tapapkkoro yaitu sikap perenungan dan penghayatan untuk lebih mengenal sang Khalik". Lanjut Amma Toa.

Pertanyaan Amma Toa di atas sungguh luar biasa, di tengah proses dakwah yang terus dilakukan kalangan tertentu terhadap mereka, karena dianggap Ke-islamannya belum sempurna, masih banyak takhayul dan 
$\begin{array}{lrr}\text { musyrik, Amma } & \begin{array}{r}\text { Toa } \\ \text { balik }\end{array} & \text { Justru } \\ \text { mempertanyakan }\end{array}$ sesungguhnya yang musyrik? Apakah komunitas tanah Toa yang begitu menjaga konstruk tentang tuhan, ataukah orang luar yang mengaggap Islamnya paling resmi?.

\section{PENUTUP}

Secara keseluruhan, praktik yang dilakukan oleh komunitas Tanah Toa Kajang ini dianggap sebagai Islam Patuntung. Hal ini pernah dikemukakan oleh A.A. Cence dalam De Patoentoengs in Het van Kajang dalam edisi bahasa Inggris yaitu Patuntung in Mountain Of Kajang (AA. Cence; 1931), Aminah dalam Nilai-nilai Luhur Budaya Spritual Masyarakat Amma Toa Kajang (Aminah, 1989). G.F. de Jong dalam Ilalang Arenna (De Jong, 1996). Keyakinan semacam ini dianggap menyebar di beberapa tempat di Sulawesi Selatan mulai dari Gowa, Takalar, Bantaeng, Bulukumba, sebagian Sinjai dan sebagian Pangkep. Komunitas Tanah Toa Kajang dianggap sebagai pusat dari ajaran Patuntung ini. Istilah Patuntung dalam Bahasa Konjo bermakna beberapa hal diantaranya: Belajar: yaitu orang yang menuntut ilmu kebatinan dan ilmu-ilmu yang berkaitan dengan religi untuk lebih mengenal Tuhan. Puncak atau ketinggian: sesuatu yang menjadi batas terakhir pencarian seseorang. Seseorang penganut patuntung akan berupaya menjcapai tingkatan ini. Mencari, yaitu satu kemauan yang keras dengan tekad bulat berupaya mendapatkan apa yang dicarinya, jadi bukan sekedar mencari, tetapi disana ada kemauan keras untuk mendapatkan apa yang dicari.

Islam Patuntung ini adalah sebuah terma untuk menunjukkan Islam khas lokal. Sebuah model dialog, negosiasi dan adatasi tradisi lokal terhadap apa yang dianggap universalisme. Islam Patuntung dapat pula dimaknai sebagai sebuah reistensi lokal terhadap agama yang dianggap universal. Ini juga menunjukkan bahwa yang lokal tidak betul-betul diam dalam berhadapan dengan kekuatan yang dianggap pusat dan universal.

Komunitas Tanah Toa pada akhirnya memang mengikuti ajaran Islam, melakukan peniruan dalam beberapa ritualnya namun disaat bersamaan mereka memunculkan pula sisi-sisi pengejekan, subversif dan penyempalan. Dalam hal ini bolelah kita baca dari pembacaan Homi Bhabha sebagai mimikri dan ambivalensi. Maka mengangkat cerita yang lokal dan subversif semacam ini bukanlah soal sekedar kembali kemasa lalu dan proyek romantisasi, tetapi ini seperti kata Partha Chatterje membangkitkan suara-suara lokal, yang subversif dan yang meyempal sebagai bagian dari resistensi terhadap yang pusat, yang baku dan diresmikan.

Namun selain itu, yang terpenting kita baca dalam konteks ini adalah keberhasilan komunitas ini menegoisasikan antara ajaran Patuntung dengan ajaran Islam yang datang kemudian. Dengan kreatifitas yang mereka miliki, mereka berhasil menerjemahkan Islam sesuai dengan lokalitas dimana mereka berada. Persis kata Amma Toa (pimpinan adat Tanah Toa): Naia agamaia nikalimbuki ri adaka. Artinya: Adapun agama, yang menyelimutinya adalah adat dan kebudayaan (Amma Toa)

Hal ini sekaligus menunjukkan kepada kita bahwa agama ini sesungguhnya tidaklah tunggal, ia bisa berdialog dan membumi sesuai dengan tempatnya. Tinggal kini yang ditunggu adalah kreatifitas yang cerdas dari 
pemeluknya, bisakah mendialogkan Islam dengan lokalitas di mana mereka berada, atau malah menjadi komunitas yang kaku yang tidak bisa dengan luwes menuntun ajaran Islam berdialog dengan lokal dan zamannya. Komunitas Tanah Toa Kajang telah mengajarkan kita tentang itu.

\section{UCAPAN TERIMA KASIH}

Penulisan artikel ini adalah hasil dari sebuah penelitian lapangan yang melibatkan bantuan dari banyak berbagai unsur masyarakat. Karena itu, saya mengucapkan terimakasih yang setinggi-tingginya kepada pendamping desa, tokoh adat dan tokoh agama dari masyarakat Tanah Toa Kajang. Terima kasih juga kepada pembingbing penelitian ini yang banyak memberikan kritik dan saran untuk perbaikan artikel ini.

\section{DAFTAR PUSTAKA}

Adhan, S. (2005). Islam dan Patuntung di Tanah Toa Kajang: Pergulatan Tiada Akhir.

Akib, Y. (2003). Ammatoa Komunitas Berbaju Hitam. Makassar: Pustaka Refleksi.

Bahtiar. (2012). Islamisasi di Tiro, Bulukumba. periode JuniNovember 2012. Alqalam, Juni.

Bhaba, H. (1997). "Of Mimicry and Man": The ambivalen of Colonial Discourse" Barkeley: University of California Press. In Frederick Cooper dan Ann Laura Stoler (eds), Tensions of Empire: Colonial Cultures in a Bourgeois World.

Cahaya. (2014). Proses Islamisasi di Kajang Bulukumba (Suatu Tinjauan Historis). Fakultas Adab IAIN Alauddin Ujung Pandang.

Cence, A. A. (1931). The Patuntungs in the Mountains of Kajang . Makassar: Naskah/Catatan laporan di KITLV.

Gibson, T. (2009). The Sun Pursued The Moon: Symbolic knowledge and Traditional Authority among the Makassar. Diterjemahkan Nurhady Sirimorok. 2009. Inninnawa.

Hasyim, P. (1981). Islam di Kajang Suatu Analisa Sosial Historis.

Katu, M. A. (1980). Hubungan Pasang dengan Ammatowa di Kajang.

Mappasomba, A. (2012). Palammai, Ramli \& . Sejarah Eksistensi Ada Lima Karaeng Tallua di Kajang. Dinas Kebudayaan dan Pariwisata Kabupaten Bulukumba.

Mattulada. (1961). Ammatowa Salah Satu Manifestasi Kebudayaan di Indonesia.

Parekh, B. (2004). Rethinking Multikulturalisme: Cultural Diversity and Political Theory. London: Macmilland Press.

Sindhunata. (1983). Dillema Usaha Manusia Rasional: Kritik Masyarakat Modern oleh Max Horkheimer dalam Rangka Sekolah Frankfurt. Jakarta: Gramedia.

Sitti., A. (1989). Nilai-Nilai Luhur Budaya Spiritual Masyarakat Ammatowa Kajang. Makasaar.: Kanwil Depdikbud Propinsi Sulawesi Selatan.

Tsing, A. L. (1998). In The Realm of Diamond Queen: Marginality in an Out of Way Place. Di Bawah Bayang- bayang Ratu Intan Proses Marjinalisasi Pada masyarakat Terasing. Princeton University Press.

Usop, K. M. (1978). Pasanga ri Kajang: Kajian Sistem Nilai di Benteng Hitam Ammatowa. 
Indeks Judul

Vol. 8, No. 2, November 2020

Islamisasi di Ajatappareng Abad XVI-XVII, 191

Jaringan Intelektual Ulama Pinrang, 227

Kearifan Lokal Sintuwu Maroso sebagai Simbol Moderasi Beragama, 241

Korelasi Fungsional Kalender Islam dan Pembayaran Zakat, 179

Makna dan Simbol Pada Tradisi Pembacaan Ratek Mauduk di Komunitas Makassar, 165

Mengilhami Kreativitas Keberagamaan Masyarakat Melalui Perjumpaan Islam dan Patuntung di Tanah Toa Kajang, 145

Merajut Moderasi Beragama dari Tradisi Pesantren, 211

Tradisi Siklus Hidup Masyarakat Perkotaan di Era Normal Baru (Studi Living Qur'an Pada Masyarakat Pedalangan, Banyumanik, Semarang), 125 
Indeks Penulis

Vol. 8, No. 2, November 2020

Abd. Kadir M, 211

Ahmad Yani, 191

Husnul Fahimah Ilyas, 165

Mita Melina, Ulfi Putra Sany, dan Mustolehudin, 125

Muh. Rasywan Syarif dan Naif, 179

Muhammad Nur, 241

Syarifuddin, 227

Sylviah dan Abu Muslim, 145 


\section{Ketentuan Pengiriman Tulisan \\ Pusaka Jurnal Khazanah Kegamaan}

Pusaka Jurnal Khazanah Keagamaan adalah terbitan yang bersifat ilmiah, berisi tulisan hasil penelitian dan kajian dalam bidang Khazanah Keagamaan. Artikel yang dikirim ke redaksi diharapkan mengikuti ketentuan sebagai berikut:

> Naskah harus berupa hasil penelitian atau kajian pustaka yang belum dan tidak dalam proses publikasi pada media cetak lain, dikirim dalam bentuk file word doc ke OJS web: https://blamakassar.ejournal.id/pusaka/index jika mengalami kesulitan dapat menghubungi admin melalui email: pusakajurnal@gmail.com

$>$ Naskah diketik dengan spasi 1 di atas kertas ukuran A4, dengan huruf Times New Roman 12. Batas semua sisi kiri dan bawah $4 \mathrm{~cm}$, atas dan kanan $3 \mathrm{~cm}$. Jumlah kata minimla 5000 dan maksimal 10000 atau sekitar 15-20 halaman, menggunakan bahasa Indonesia, bahasa Inggris, atau bahasa Arab, disusun dengan urutan sebagai berikut:

Penulisan artikel hendaknya memenuhi unsur-unsur berikut:

Judul: tidak lebih dari 15 kata

Nama

Intansi

Alamat

Email

Abstract: minimial 180, maksimal 200 kata, terdiri dari 2 kalimat dari setiap bagian artikel

Keywords: (5 keywords) $=3$ kata berasal dari judul

Introduction (4 paragraf)

Paragraph 1 (Fakta)

$>$ Shocking statement

$>$ Penjelasan sedikit tentang tema yang akan diangkat

$>$ Data

$>$ Pernyataan ahli tentang topik yang akan dibahas

\section{Paragrpah 2 (Fakta literature)}

$>$ Aspek yang sudah diteliti (3 - 4 literature)

$>$ Kutipan (1-2) literature yang menjelaskan fakta

$>$ Ditutup dengan gap (aspek yang belum diteliti yang berhubungan dengan topik tersebut)

Paragraph 3: Tujuan penelitian. Misalnya tulisan ini bertujuan untuk: Melengkapi, menjelaskan, memetakan

Paragraph 4: Argumen/hipotesis/ asumsi/ kesimpulan awal 1, 2 dst...

Literature Review (agar tidak DUPLIKASI/plagiat, dan untuk meminjam konsep-konsep yang telah dipakai peneliti terdahulu) (9-10 paragraf)

$>$ Profil penelitian sebelumnya, kecenderung dan tipologi (aspek/isu yang dikaji cenderung? Pendekatan yang digunakan cenderung? Hasil yang diperoleh apa??) (1-2 paragraf)

$>$ Definisikan konsep2 penting (6 paragraf)

Method (3-5 paragraf)

Pilihan objek (tempat, kasus, isu)

Jenis penelitian: kualitatif/survey $=>$ data yang diperlukan

$>$ Sumber informasi: informan atau responden

$>$ Teknik pengumpulan data: observasi, wawancara (siapa? Berapa orang?), content analysis (mapping)

$>$ Analisis: proses analisis (tahapan analisis) dan teknik analisis (interpretasi) 
Results: BUKTI BUKTI / Penyajian Dan Pengkategorian DATA ( Jawaban WHAT??)

Discussion: PEMBAHASAN=MENGAPA (Menjawab SO-WHAT? WHY??)

Conclusion (3 paragraf)

$>$ Temuan terpenting? Apa yang baru kita tahu setelah ada penelitian? (Ternyata!)

$>$ Apakah teori/konsep/metode yang digunakan dapat menjawab pertanyaan penelitian?

$>$ Keterbatasan penelitian? Saran penelitian lanjutan....

Ucapan terimakasih, kepada mereka yang banyak memberikan bantuan dalam tulisan tersebut.

Daftar Pustaka, minimal 16 judul, dan 80\% acuan yang digunakan dari terbitan 10 tahun terakhir dan hendaknya $80 \%$ acuan berupa sumber primer. Daftar pustaka hanya sumber yang terdaftar dalam tulisan, bukan daftar bacaan, ditulis dan disusun secara abjad dengan mengacu pada american psychological association (apa) style 6th edition, diharuskan menggunakan aplikasi MENDELEY atau sejenisnya.

Semua jenis rujukan harus diintegrasikan dengan sistem aplikasi mendeley atau sejenisnya, apabila merujuk dari sumber internet, hendaknya mengambil sumber yang bertanggung jawab dengan mengetahui nama, organisasi, atau pihak yang bertanggung jawab atas pernyataan yang dikutip.

\section{Ketentuan tambahan:}

Tabel, gambar, dan grafik diberi nomor urut; ilustrasi tersebut harus jelas terbaca. Judul tabel ditulis di sebelah atas tabel yang bersangkutan, sedangkan judul gambar dan gambar di sebelah bawah ilustrasi masing-masing.

Tulisan yang menggunakan transliterasi Arab-Latin, penulis hendaknya berpedoman pada Pedoman Transliterassi Arab-Latin SKB Dua Menteri, Menteri Agama RI Nomor 158 Tahun 1987 dan Menteri Pendidikan dan Kebudayaan RI Nomor 0543 b/u/1987 tentang Pedoman Transliterasi Arab Latin.

\section{Seleksi Tulisan}

- Proses seleksi naskah meliputi: seleksi awal, penyuntingan oleh Dewan Redaksi, Review (penelaahan) oleh Mitra Bestari, dan persetujuan naskah.

- Kriteria penilaian mencakup kesesuaian dengan persyaratan, sistematika, derajat originalitas alur penulisan, kedalaman ilmiah, unsur kebaruan (novelty), nilai manfaat hasil penelitian.

- Menanda tangani surat keterangan klirens etik atau tidak plagiasi

- Redaksi berhak menolak, mengembalikan untuk diperbaiki atau mengedit kembali naskah tanpa merubah isi dan maskud tulisan.

\section{Lain-lain}

- Redaksi tidak bertanggung jawab setiap pernyataan dan pendapat yang dikemukakan penulis

- Artikel dalam bentuk file word doc dikirim melalui OJS, di laman web: https://blamakassar.ejournal.id/pusaka/index jika mengalami kesulitan dapat menghubungi admin melalui email: pusakajurnal@gmail.com 